\title{
PENGELOLAAN RETRIBUSI PASAR AENG TOWA TERHADAP PENINGKATAN PENDAPATAN ASLI DAERAH DI KABUPATEN TAKALAR
}

\author{
${ }^{1}$ Sarmila, ${ }^{2}$ Muhlis Madani, ${ }^{3}$ Abdul Mahsyar \\ 1) Jurusan Ilmu Administrasi Negara Fisipol Unismuh Makassar \\ 2) Jurusan Ilmu Administrasi Negara Fisipol Unismuh Makassar \\ 3) Jurusan Ilmu Administrasi Negara Fisipol Unismuh Makassar
}

\begin{abstract}
The objective of the research is to know the management of aeng towa market levies to increase local revenues and factors inhibiting and supporters in the district Takalar. The type of research is descriptive qualitative which has eigth informants. The data collecting techniques used observation and interview. The data was analyzed using descriptive technique. The research results show that the management of the market retribution aeng towa not in accordance with the target that has been set as traders are still not consistent in paying the market tax. There is another factors that became the obstacles of this Aeng Towa market tax management that the market capacity is still limited.
\end{abstract}

Keywods: efforts to increase, obstacle, management levy

\begin{abstract}
ABSTRAK
Adapun tujuan dilakukannya penelitian ini ialah untuk mengetahui bagaimana pengelolaan Retribusi pasar Aeng Towa terhadap peningkatan pendapatan asli daerah dan faktor penghambat dan pendukung di Kabupaten Takalar. Jenis penelitian adalah deskriptip kualitatif dengan informan 9 orang. Teknik pengumpulan data dikumpulkan dengan menggunakan instrument berupa observasi, wawancara terhadap informan. Data tersebut dianalisis secara deskriptif. Hasil penelitian ini menunjukkan bahwa pengelolaan retribusi pasar Aeng Towa belum sesuai dengan target yang telah di tentukan karena pedagang yang masih belum konsisten dalam membayar retribusi pasar. Faktor penghambat pengelolaan retribusi Pasar Aeng Towa yaitu daya tampung pasar terbatas.
\end{abstract}

Kata kunci: upaya peningkatan, hambatan, pengelolaan retribusi 


\section{PENDAHULUAN}

Pembiyaan pemerintah daerah dalam melaksanakan tugas pemerintah dan pembangunan senantiasa memerlukan sumber penerimaan yang dapat diandalkan. Kebutuhan ini semakin dirasakan oleh daerah terutama sejak diberlakukannya otonomi daerah di Indonesia, yaitu mulai tanggal 1 Januari 2001. Dengan adanya otonomi daerah, daerah di pacuh untuk dapat berkreasi mencari sumber penerimaan daerah yang dapat mendukung pembiayaan pengeluaran daerah. Dari berbagai alternative sumber penerimaan yang mungkin di pungut oloeh daerah, Undang-undang tentang pemerintah daerah menetapkan pajak dan retribusi daerah menjadi salah satu sumber yang berasal dari dalam daerah dan dapat di kembangkan sesuai dengan kondisi masingmasing daerah.

Pemungutan pajak daerah dan retribusi daerah di atur dalam undang-undang Nomor 18 Tahun 1997 sebagaimana di sempurnakan dengan undang-undang Nomor 34
Tahun 2000 tentang pajak daerah dan retribusi Daerah. Berdasarkan keputusan menteri keuangan pada rapat paripurna dewan perwakilan rakyat republic Indonesia tanggal 18 Agustus 2009 undang-undang No 34 Tahun 2000 tentang fajak daerah dan retribusi daerah, dig anti menjadi undang-undang No. 28 Tahun 2009 tentang pajak daerah dan retribusi daerah. Memperbaiki tiga hal,yaitu:penyempurnaan system pemungutan pajak daerah dan retribusi daerah,pemberian kewenangan yang lebih besar kepada daerah dibidang perpajakan,dan peningkatan efektivitas pengawasan.Ketiga haltersebut berjalan secara bersamaan,sehingga upaya peningkatan pendapatan asli daerah (PAD) dilakukan dengan tetap sesuai dan konsisten terhadap prinsip-prinsip perpajakan yang baik dan tepat, dan pengenaan sanksi apabila terjadi pelanggaran. Dalam hal ini penerimaan retribusi pasar cukup potensial untuk di kembangkan di Kabupaten Takalar karena merupakan salah satu jenis retribusi yang potensial untuk dikembangkan mengingat jumblah 
pemasukan dari sector tersebut cukup menunjang untuk pembangunan pasar di Kabupaten Takalar.

Pendapatan asli daerah merupakan hal yang sangat penting dalam proses pembanmgunan daerah. Salah satu masalah cukup besar pascotonomi daerah adalah ketergantungan pemerintah daerah terhadap dana perimbangan dari pemerintah pusat. Hal ini dikarenakan masih lemahnya kemampuan pemerintah daerah dalam mengelola potensi yang ada di dearah sehingga dapat meningkatkan pendapatan asli daerah. Oleh karena itu, di butuhkan menejemen pendapatan agar setiap daerah dapat memahami potensi pendapatan mereka dan juga dapat memaksimalkan pendapatan mereka untuk membiayai keinginan pemerintah dan pelayanan public. Masalahnya 2 tahun terakhir (20142015)yaitu pendapatan asli daerah pada Kabupaten Takalar dalam sektor retribusi tidak mencapai target.Dari $16 \mathrm{M}$ tapi yang dicapai hanya $13 \mathrm{M}$ atau sekitar 60\%
saja.Dari jumlah tersebut hanya retribusi penerangan jalan saja yang mencapai target bahkan melampaui hingga 104\% maka pengelolaan retribusi pasar perlu ditingkatkan lagi agar pendapatan asli daerah dapat tercapai sesuai target.

Soegiyanto (2003:249), bahwa pengelolaan adalah: a). proses atau pembuatan kebijakan b). menjalankan proses,melakukan kegiatan tertentu dengan menggerakkan tenaga orang lain $\mathrm{c}$ ). proses yang membantu merumuskan kebijakan dan tujuan organisasi d). proses yang memberikan pengawasan pada semua hal yang terlibat dalam pelaksanaan kebijakan dan pencapaian tujuan.

Pengelolaan menurut Hamalik $(1993,18)$ dalam hal ini identik dengan istilah manajemen itu sendiri yaitu merupakan suatu proses. Berdasarkan pendapat tersebut, dapat disimpulkan bahwa pengertian pengelolaan berkaitan dengan penerapan fungsi-fungsi manajemen dalam suatu kegiatan organisasi untuk mencapai tujuan yang telah ditentukan. 
Suharsimi Arikunto (1993:31), pengelolaan dapat disamakan dengan manajeme yang berarti pula pengaturan atau pengurusan. Sedangkan Adisasmita (2011:22) mengemukakan bahwa pengelolaan bukan hanya melaksanakan suatu kegiatan, akan tetapi merupakan rangkaian kegiatan yang meliputi fungsi-fungsi manajemen seperti perencanaan, pengorganisasian, pelaksanaan dan pengawasan untuk mencapai tujuan secara efektif dan efesien.

Menurut Harsoyo (1997:121) pengelolaan adalah suatu istilah yang berasal dari kata "kelola" mengandung arti serangkaian usaha yang bertujuan untuk menggali dan memanfaatkan segala potensi yang dimiliki secara efektif dan efesienguna mencapai tujuan tertentu yang telah direncanak an sebelumnya.

\section{Perencanaan merupakan} landasan pokok dan menjadi salah satu fungsi manajemen yang memegang peranan penting dalam menjamin tercapainya tujuan yang diinginkan. Dalam penyusunan rencana yang baik, butuh data dan informasi yang akurat dari penelitian dan pembuktian lapangan.

F.X.Soedjadi dalam syafiie dkk (1999:76) memberikan definisi perencanaan sebagai proses kegiatan pemikiran, dugaan, dan penentuan prioritas yang dilakukan secara rasional. Sebelum melaksanakan tindakan yang sebenarnya dalam rangka mencapai tujuan yang di tetapkan. Sementara Siagian dalam bukunya filsafat administrasi menjelaskan bahwa perencanaan (planning) adalah keseluruhan proses pemikiran dan penentuan secara matang tentang hal-hal yang akan dikerjakan di masa yang akan datamg dalam rangka pencapaian tujuan yang telah di tentukan.

Pengelolaan menurut Leiper (19 90:256 dalam I Gde dan Surya Diarta, 2009:80), merujuk kepada seperangkat peranan yang dilakukan seseorang atau sekelompok orang, atau bias juga merujuk kepada fungsi-fungsi yang melekat pada peran tersebut. Fungsi-fungsi manajemen tersebut adalah sebagai berikut : a) Planning (perenc 
anaan), Perencanaan menyangkut strategi sebagai inplementasi dari kebijakan. Perencanaan merupakan prediksi dan oleh karenanya memerlukan beberapa perkiraan persepsi akan masa depan. Walau prediksi dapat diturunkan dari observasi dan penelitian, namun demikian juga sangat tergantung pada tata nilai. Perencanaan merupakan bagian dari keseluruhan proses perencanaan pengambilan kep utusan pelaksanaan. b) Directing (me ngarahkan) Penggerakan dapat didef enisikan sebagai keseluruhan proses pemberian dorongan bekerja kepada para bawahan sedemikian rupa sehingga mereka mau bekerja dengan ikhlas demi tercapainya tujuan organisasi dengan efesien dan ekonomis, c) Org anizing (termasuk coordinating) Pen gorganisasian sebagai fungsi organik administrasi dan manajemen ialah ke seluruhan proses pengelompokan orang-orang, alat-alat, tugas-tugas, tanggung jawab, dan wewenang sedemikian rupa sehingga tercipta suatu organisasi yang dapat di gerakkan sebagai suatu kesatuan dalam rangka pencapaian tujuan yang telah ditentukan., d) Con trolling (pengawasan) Dari fungsifungsi manajemen terdahulu tidak akan efektif tanpa fungsi pengawasan (controlling), atau sekarang banyak digunakan istilah pengendalian, menurut Handoko (1999:25), pengawasan adalah penemuan dan penerapan cara dari peralatan untuk menjamin bahwa rencana telah dilaksanakan sesuai dengan yang telah ditetapkan.

Dari uraian diatas dapatlah disimpulkan bahwa pengeloaan adalah suatu rangkaian yang berintikan

perencanaan, pengorganisasian, pen gawasan dan penggerakan yang $b$ ertujuan menggali dan memanfaatka sumber daya alam yang dimiliki secara efektif untuk mencapai tujuan organisasi yang telah ditentukan.

\section{Proses perencanaan dapat} ditinjau dari tiga segi, dengan perkataan lain bahwa fungsi perencanaan dapat dilaksanakan dengan baik melalui tiga cara. Caracara tersebut yaitu pertama, mengetahui sifat-sifat atau ciri-ciri suatu rencana yang baik. Setelah 
cirri-ciri itu diketahui lalu diusahakan agar rencana yang dibuatmemenuhi syarat-syarat tersebut. Kedua,memandang proses perencanaan sebagai suatu rangkaian pertanyaan yang harus dijawab dengan memuaskan. Rudyard Kipling, sastrawan inggris yang terkenal pernah mengatakan bahwa dalam hidupnya ia mempunyai enam pelayan yang baik yang bernama: what, where, when, why, who dan how. Para ahli administrasi dan manajemen telah "meminjam" konsep tersebut dan menerapkannya dalam bidang administrasi dan manajemen, dalam hal ini dalam bidang perencanaan. Ketiga, memandang proses perencanaan sebagai suatu masalah yang harus dipecahkan dengan mempergunakan teknik-teknik ilmiah. Dalam menerapkan prinsipprinsip pemecahan masalah dengan teknik ilmiah, pimpinan dapat pula menciptakan suatu rencana yang baik, dengan perkataan lain pembuatan suatu rencana dapat dipandang sebagai masalah yang harus terpecahkan dengan sistematis.
Menurut

Siagian pengorganisasian adalah keseluruhan proses pengelompokan orang-orang alat-alat,tugas-tugas,tanggung jawab,dan wewenang sedemikian rupa sehingga tercipta suatu organisasi yang dapat digerakkan sebagai suatu kesatuan dalam rangka pencapain tujuan yang telah ditentukan .

Menurut siagian dalam syafiie dkk (1999:83) bahwa pengawasan merupakan proses pengamatan dari pelaksana seluruh kegiatan organisasi untuk menjamin agar seluruh pekerjaan yang dilaksanakan sesuai dengan rencana yang telah ditentukan sebelumnya.

Siswanto Sastrohadiwijoyo (2003:26) pengawasan merupakan suatu proses dan rangkaian kegiatan untuk mengusahakan agar suatu pekerjaan dapat dilaksanakan sesuai dengan rencana yang telah ditetapkan dan tahapan yang harus dilalui. Pemgawasan mutlat diperlukan agar dalam pelaksanaanya seminimal mungkin dapat dihindari segala ketimpangan dari apa yang telah disusun sebelumnya. 


\section{METODE PENELITIAN}

Jenis penelitian deskriptif yaitu penelitian yang mengutamakan data dalam bentuk kalimat/ pertanyaan yang bersumber dari data primer/informan. Tipe penelitian kualitatif yaitu menhadirkan gambaran tentang situasi atau phenomena social secara detail. Jenis penelitian adalah deskriptif kualitatif dengan informan sembilang orang, teknik pengumpulan data dikumpulkan dengan menggunakan instrument berupa observasi ialah metode penggumpulan data dengan cara melakukan pengamatan langsung terhadap cara kerja aparat dalam melayani masyarakat. Wawancara metode yang dilakukan dengan cara tanya jawab, sambil bertatap muka antara pewawancara dengan informan dengan menggunakan interview guide (pedoman wawancara/daftar pertanyaan) yang telah disiapkan.

Sumber data utama dalam penelitian kualitatif ialah kata-kata dan tindakan selebihnya adalah data tambahan seperti dokumen dan lainlain. Dimana data hasil penelitian didapatkan melalui dua sumber data, yaitu data sekunder dan data primer. Data tersebut dianalisis secara deskriptif diinterprestasi pada informan dengan melakukan wawancara langsung kemudian mengecek kembali data tersebut untuk memahami secara mendalam serta teori-teori yang sesuai dengan data tersebut yang dikumpulkan agar dapat menghasilan penelitian bermutu.

\section{HASIL DAN PEMBAHASAN}

Target retribusi tidak tercapai kar Pengelolaan atau yang sering disebut manajemen merupakan suatu proses,yang diartikan sebagai usaha yang sistematis untuk menjalankan suatu pekerjaan proses ini merupakan serangkaian tindakan yang berjenjang, berlanjut dan berkaitan dilakukan untuk mencapai tujuan yang telah ditetapkan. Proses tersebut merupakan kaitan antara fungsi dari manajemen itu sendiri yang terdiri atas perencanaan, pengorganisasian, penggerakan dan pengawasan.

Demikian pula pada pengelolaan penerimaan retribusi 
pasar Aeng Towa di Kab.Takalar yang dalam hal ini di kelola oleh Dinas Pendapatan Daerah senantiasa menerapkan fungsi-fungsi manajemen dalam pengelolaannya agar dalam pelaksanaannya senantiasa merujuk pada upaya pencapaian tujuannya.na adanya wajib retribusi yang masih acuh tak acuh dalam persoalan membayar Retribusi yang iya nikmati sendiri.

Guna merealisasi target diatas Dinas pendapatan Daerah sangat bekerja keras dalam tercapainya segala rencana yang iya buat agar pencapaian target Retribusi Pasar bisa iya capai setinggi mungkin sehingga pendapatan Daerah dalam hal Retribusi biasa mengalami peninggakatan setiap tahunya agar tidak mengalami penurunan sehingga bisa bersaing dengan Daerah Lain.

Perencanaan dalam hal penetuan target penerimaan retribusi pasar Aeng Towa pertahunnya senantiasa dilakukan berdasarkan potensi yang ada dan sangat tergantung pada realisasi pertahun yang dapat tercapai. Namun tidak adanya data yang akurat tentang potensi yang dimiliki oleh pasar serta pembangunan pasar membuat realisasi penerimaan retribusi pasar tidak sesuai yang direncanakan. peran dari Dinas pendapatan Daerah cukup baik karena adanya kepedulian yang dia lakukan mesti bukan dia lansung yang turung tangan memberi bantuan dalam hal ini pimjaman bagi para pelaku pedagang melainkan adanya kerja sama oleh dinas koperasi.

Kegiatan tinjauan yang seperti itu sepatutnya harus di lakukan setiap saat karna guna melihat keluhankeluhan yang di butuhkan para pedangangyang ada di pasar sehingga Dinas pendapatan Daerah melihat secara lansung keadaan dilapangan.

Sikap yang dilakukan seorang kolektor kepada wajib retribusi dalam menangih retribusi wajarwajar saja jika sekali-kali mengancam kepada wajib retribusi yang suka malas-malasan dalam membayar retribusi demi kebaikan bersama selama tindakan yang di ambil tidak melampaui batas. Para sstaf kantor Dinas pendapatan Daerah dalam memerintah para bawahnnya sangatlha tegas guna Website : http://journal.unismuh.ac.id/index.php/kolaborasi 
member motifasi kepada bawahansupaya tidak semaunya saja dalam melaksanakan tugas. Agar perlaksanaan tugas berjalan dengan baik maka harus ada pembagian tugas yang baik agar dalam pelaksanaan pemungutan dapat berjalan dengan efektif dan lancar sehingga sehingga pemungutan retribusi Pasar Aeng Towa semua pedagang tidak ada yang tidak membayar retribusi. Sifat kekeluargaan itu dapat terjalin dengan baik karena adanya kebersamaan setiap hari yang dilakukan di pasar serta sesekali mereka bercanda jika tidak ada pelanggan. Pelanggan harus di layani sebaik mungkin karena tampa pelanggan kita sebagai pedangang pasti tidak berarti apa-apa. Keberadaan pasar ini sangat member mamfaat bagi para masyarakat yang sangat terbantu karena mudahnya mencari sesuatu tampa harus jauh-jauh turung di Makassar hanya untuk mencari kebutuhan rumah tangga.

Metode pemungutan tarif retribusi kepada pengguna fasilitas pasar di lakukan dengan cara Website : http://journal.unismuh.ac.id/index.php/kolaborasi mendatangi lansung para wajib retribusi ditempat mereka berjualan. Ini dilakukan agar pemungutan retribusi tidak mengganggu proses jual beli para wajib retribusi dan memastikan bahwa tidak ada wajib retribusi pasar yang tidak membayar retribusi. Mengingat jumlah pengguna pasar di pagi hari maka kepala UPTD memerintahkan agar lebih mendahulukan pemungutan pada pengguna pasar pagi terutama pengguna pelataran terbuka dimana diketahui bahwa pengguna tersebut dalam melakukan aktifitasnya hanya sebentar tidak sama dengan pengguna lainnya yang punya tempat khusus didalam pasar.

Untuk memudahkan para kolektor dalam pemungutan retribusi maka kepala UPTD pasar Aeng Towa membagi dua wilayah pemungutan personilnya, ini dilakukan agar para kolektor mengetahui dengan jelas wilayah pemungutannya sehingga tidak ada wajib retribusi yang tidak mebayar kewajibannya. Adapun aspek yang paling penting dalam pemungutan retribusi adalah waktu dan tempat 
serta besarnya biaya pemungutan. Untuk wajib retrbusi yang tidak menetap pada suatu los atau kios atau gardu diprioritaskan pemungutan lebih awal.Pedagang sayur-sayuran yang biasanya mulai braktifitas di pagi hari dan pulang cepat ketika jualanya sudah habis, untuk wajib retribusi tersebut biasanya dipungut lebih awal dibandingkan dengan pedagang yang sudah mempunyai tempat yang khusus didalam pasar.

Pemungutan retribusi pasar para kolektor lebih mendahulukan pedagang-pedagang yang tidak mempunyai tempat khusus didalam pasar, ini dilakukan agar para penjual (wajib retribusi) membayar kewajibannya dahulu sebelum meninggalkan pasar. Tapi sekarang kios tersebut sudah di pesan oleh para pedagang yang mempunyai omset yang cukup besar untuk melakukan transaksi setiap hari contohnya penjual emas, penjual elektronik, penjual barang-barang pecah dan lain sebagainya sedangkan tarif yang paling kecil yaitu Gardu dan pelataran yang peruntuhkan untuk penjual-penjual kecil Website : http://journal.unismuh.ac.id/index.php/kolaborasi alasan bagi para kolektor mengeluh dalam hal penagihan retribusi.

Fasilitas-fasilitas yang ada di pasar Aeng Towa belum cukup memadai karena masih ada yang dalam tahap pembangunan serta 
masih banyaknya yang berjualan di jalan masuk pasar itu semua harus di sediakan tempat di dalam pasar sehingga tidak mengganggu para pengunjung lain yang mau lewat. kerja sama yang dilakukan antara atasan dan bawahan yang dilakukan kantor Pendapatan Daerah itu sangat memberi contoh yang baik bagi kantor lain .

Pengarahan yang dilakukan kepala bidang penerimaan Dinas Pengelolaan Keuangan dan Asset Daerah kepada para kolektor hanya sebulan sekali, pengarahan ini masih harus ditambah insentitas waktunya karna mengingat masi ada penyimpangan - penyimpangan yang dilakukan oleh para kolektor seperti keterlambatan jam kerja yang sangat berpengaruh pada jumlah penerimaan retribusi yang dapat terealisasi. Bentuk penggerakan yang lain bisa juga di lihat dari bagaimana sitem penggajian para kolektor/pemungut retribusi pasar Aeng Towa dan adakah reword yang

Di berikan jika target yang direncanakan bisa tercapai. Tarif pungutan retribusi pasar Aeng Towa di Kab. Takalar sudah cukup ringan tidak memberatkan oleh para wajib retribusi dan sudah sepadam dengan fasilitas yang ditempati oleh para penjual (wajib retribusi). system penggajian para kolektor yang kadang-kadang terlambat membuat mereka tidak semangat dalam melaksanakan tugasnya, pemerintah daerah harus benar-benar memperhatikan hal ini karena ini sangat berpengaruh pada kinerja para kolektor.

Kepala UPTD pasar Aeng Towa sebagai penaggungjawab penerimaan retribusi pasar setiap hari pasar turun kelapangan mengawasi para personilnya dalam melaksanakan pemungutan retribusi pasar untuk menghindari terjadinya penyimpangan, penyelewengan, hambatan, kesalahan dan sebagainya yang dapat menghambat pencapaian penerimaan retribusi pasar Aeng Towa di Kab.Takalar.

Pegawasan yang dilakukan oleh Dinas Pendapatan Daerah hanya mengandalkan laporan-laporan semata untuk itu perlu melakukan pengawasan yang rutin kepasar guna melihat secara lansung pelaksanaan pemungutan retribusi pasar dan Website : http://journal.unismuh.ac.id/index.php/kolaborasi 369 
menilai apakah pelaksanaan pemungutan retribusi pasar sudah sesuai dengan apa yang direncanakan dan tidak hanya berfokus pada pengawasan terhadap laporan yang sudah masuk. dimana hal seperti itu sangatlah baik jika melakukan pemantauan secara tidak lansung dimana adanya seseorang yang bisa kita suruh untuk memantau kegiatan para kolektor di lapangan apakah ia benar-benar melaksanakan tugasnya atau bermain-main.

\section{Penggerakan atau actuating} adalah suatu tindakan untuk mengusahakan agar semua anggota kelompok berusaha untuk mencapai sasaran sesuai dengan perencanaan manajerial dan usaha-usaha organisasi.Jadi actuating artinya adalah menggerakkan orang-orang agar mau bekerja dengan sendirinya atau penuh kesadaran secara bersama-sama untuk mencapai tujuan yang dikehendaki secara efektif.Penggerakan merupakan hubungan manusia dalam kepemimpinan yang mengikat para bawahan agar bersedia mengerti dan menyumbangkan tenaganya secara efektif serta efisien dalam pencapaian tujuan suatu organisasi.Adapun variabel : a. Hubungan Manusia dengan Kepemimpinan b. Mengikat para Bawahan.

Bahwa dimana hal seperti itu sangatlah baik jika melakukan pemantauan secara tidak lansung dimana adanya seseorang yang bisa kita suruh untuk memantau kegiatan para kolektor di lapangan apakah ia benar-benar melaksanakan tugasnya atau bermain-main. Pemerintah sangatlah memiliki perang penting dalam hal apapun terutama suara para pedagang yang mau menikmati fasilitas Pasar yang ia tempati berdagang setiap hari Pasar sehingga kerja sama ini sangatlah di butuhkan. Adanya sifat kekeluargaan yang dimiliki oleh setiap pribadi para pedagang sehingga ada kenyamanan tersendiri yang di rasakan antara pedagang 1 dengan yang lain dalam melakukan transaksi jual beli di pasar.

Setiap kolektor yang
melakukan pemungutan retribusi
mereka sangatlah bersifat rama
kepada setiap wajib retribusi guna
menjaling rasa nyaman antara
/index.php/kolaborasi


penagih dan wajib Retribusi sehingga tidak terjadi hal yang di inginkan. adanya kepedulian Pemerintah yang ingin mengetahui keinginan-keinginan masyarakatnya itu sangat memberi contoh baik kepada daerah lain guna menunjang pendapatan Asli Daerah yang akhirakhir ini menurun. adanya kesepakatan bersama yang di lakukan antara para pedagang yang menjual di Pasar Aeng towa sehingga barang-barang yang ditawarkan tidak jauh bedah dengan pedagang lainnya.

pemerintah

sangat

memperhatikan para pelaku usaha dimana jika ada pedagang yang mempunyai modal yang kurang untuk menjalankan usaha maka pemerintah ikut turut serta dalam membantu mereka meskipun itu merupakan bantuan pinjaman. Pemerintah harus memantau lansung lahan yang ada di Pasar apakah sudah cukup atau masih ada pedagang yang tidak mempunyai tempat khusus dalam pasar sehingga tidak ada rasa iri para pedagang yang sudah mempunyai tempat khusus dengan yang tidak mempunyai Website : http://journal.unismuh.ac.id/index.php/kolaborasi tempat tetap dalam pasar. para pedagang seharusnya mampu membayar retribusi tepat waktu dikarnakan biaya yang di tawarkan sangatlah murah itu tidak sebanding dengan penhasilan yang di dapat setiap hari pasar, Namun para pedang acuh tak acuh dalam membayar wajib retribusi kepada kolektor pasar.

Seharusnya para pedagang harus mematok harga yang semaksimal mungkin jadi tidak mempersulit pelanggan kalangan menengah ke bawah dalam membeli sesuatu di pasar tetapi hal itu tidak berpengaruh kepada pedagang. dari fasilitas-fasilitas di pasar memang belum sepadang dengan para pedagang yang tiap hari pasar bertamba jumlahnya dimana jalanjalan yang di lalui sekitaran pasar itu penuh dengan pedagang jadi pihak pemerintah yang harus menambang lahan pasar jika masih ada yang kosong atau mengalami pembaruan pasar yang berlantai. peran atasan sangatlah penting dalam menjalankan roda pemerintahan ini karena para bawahan agak cepat melaksanakan tugas apabila atasan 
tegas dalam bertindak sehingga tidak ada bawahan yang mau main-main dalam menjalankan tugasnya sebagai bawahan.

\section{KESIMPULAN}

Pengelolaan penerimaan retribusi pasar Aeng Towa Belum stabil , dapat dilihat dari hasil penerimaan retribusi tiap tahunya yang belum mengalami kemajuan. Dan masih adanya kendala-kendala yang dihadapi oleh Dinas Pendapatan Daerah dalam memeksimalkan pencapaian yaitu : a.Perencanaan dalam hal ini penetuan target retribusi pasar pertahunya masi belum efektif karna tidak didukung oleh data-data yang akurat mengenai potensi yang dimiliki oleh pasar utamanya para pedagang yang tidak memiliki tempat di dalam pasar. b.Pengorganisasian dalam hal standar kerja sikap dari petugas/kolektor pungutan retribusi pasar yang belum mematuhi aturanaturan dalam pelaksanaannya, seperti aturan jam kerja. c.Penggerakan dalam hal penggajian para kolektor yang tidak tepat waktu membuat kinerja para kolektor tidak efektif. d.Pengwasan yang dilakukan oleh atasan dalam hal ini Kepala Bidang Penerimaan Dinas Pengelolaan Keuangan dan Aset daerah masih sangat kurang dan hanya bertumpu pada laporanlaporan hasil penerimaan perbulan saja.

\section{DAFTAR PUSTAKA}

Adisasmita, 2011. Pengelolaan Pendapatan Dan Anggaran Daerah. Graha Ilmu Yogyakarta.

Hamalik. 1993. Strategi Manajemen. Bandung : Mandar Maju.

Harsoyo. 1997. Manajemen Sumber Daya Manusia. Jakarta. PT. Bumi Aksara.

Handoko. 1999. Manajemen BPFE Yogyakarta.

I Gde Pitana, I Ketut Surya Diarta. 2009. Pengantar Ilmu Pariwisata. Yogyakarta.

Sugiono, 2012. Metode Penelitian Kuantitatif, Kualitatif Dan $R \& D$. Bandung : Alfabeta.

Siagian, 1995. Manajemen Strategik. Jakarta: PT. Bumi Aksara.

Syafiie Dkk. 1999. Ilmu Administrasi Publik. PT Rineka Cipta.

Sogianto, 2003. Analisis Kebijakan Publik, Jakarta : Jakarta Lembaga Administrasi Negara.

Suharsimi. 1993. Manajemen Penelitian. Jakarta : PT. Raja Grafindo Persada. 